\title{
Specific PCR Amplification for N-ras Mutations in Neoplastic Thyroid Diseases
}

\author{
Masahiro KAIHARA, Matsuo TANiYAMA, Junko TADATOMO*, \\ TAKAshi TOBE*, Motowo TOMITA*, Kunihiko ITO**, \\ Yoshio BAN, AND TAKASHI KATAGIRI \\ Third Department of Internal Medicine, School of Medicine, and \\ *Department of Physiological Chemistry, School of Pharmaceutical \\ Science, Showa University, Tokyo 142, and **Ito Hospital, Tokyo 142, Japan
}

\begin{abstract}
We analyzed point mutations of $\mathrm{N}$-ras protooncogene codon 61 in thyroid neoplasms by means of a mutation-specific PCR method. In this method, one of the paired primers has a base at the $3^{\prime}$ terminal that is complementary to a mutated base of the DNA sequence to be analyzed. With this primer, only alleles which have the same mutation can be amplified. Among 24 thyroid tissues, we detected 2 point mutations out of 7 follicular carcinomas (29\%). One tumor had a cytosine to adenine substitution mutation at the first base of codon 61 , and the other had an adenine to guanine substitution mutation in the second base of the same codon. The same mutations were not detected in 7 follicular adenomas or 1 papillary carcinoma. These results were confirmed by both dot blot hybridization and direct sequencing method. Mutation of $\mathrm{N}$-ras codon 61 may be significant in malignant transformation of follicular thyroid tumors. Because of its easy availability, the mutation-specific PCR method is a useful screening test for $\mathrm{N}$-ras mutations.
\end{abstract}

Key words: Mutation specific PCR, Follicular carcinoma of thyroid, N-ras oncogene.

(Endocrine Journal 41: 301-308, 1994)

THE POLYMERASE chain reaction (PCR) technique allows for the detection of DNA sequence abnormalities with minimal amounts of tissue [1]. With the general acceptance of the PCR technique, it has been shown that gene mutations are responsible for a variety of diseases. Cancer is one of the major diseases where gene mutation plays an important role. Malignant transformation has been demonstrated to be caused by several factors, such as the activation of protooncogenes and the inactivation of tumor suppressor genes [2]. For example, in the formation of colon cancer, five abnormalities of genes, which are mutation of ras, inactivation of APC, P53, DCC and an unknown

Received: November 26, 1993

Accepted: February 18, 1994

Correspondence to: Dr. Matsuo TANIYAMA, Third Dept. of Internal Medicine, Showa University Hospital, 1-5-8 Hatanodai, Shinagawa, Tokyo 142, Japan gene on chromosome 22, are thought to participate in [3-8].

In thyroid carcinoma, the activation of ras oncogene, inactivation of the p53 tumor suppressor gene, and mutation of ret gene have been identified [9-14]. In follicular carcinoma, point mutations in codons 12,13 or 61 of ras genes have been identified with an incidence of $20 \%-70 \%$. The incidence of ras gene abnormalities varies in accordance with tumor progression [15-17].

Ras genes code for sub group of $\mathrm{G}$ proteins, which are of low molecular weight (MW: 21,000) and regulate the signal transduction from cell membrane receptors to effectors [18-19]. Mutations in ras genes result in continuous activation of ras-p21 proteins, and lead to excessive accumulation of target proteins, causing malignant transformation [20].

Dot blot hybridization for PCR products is often used to detect point mutations [21] and this 
method has been applied in detecting the presence of mutations in ras gene [22]. The involvement of isotopes, however, limits the number of institutions at which this work can be conducted. We analyzed point mutations at $\mathrm{N}$-ras codon 61 in DNA samples of various thyroid tissues including neoplasms by means of the mutation-specific PCR technique [23-24], confirmed the results by dot blot hybridization and direct sequencing, and report here on the value of this type of allele-specific PCR procedure.

The mutation-specific PCR technique is an amplification procedure where one oligonucleotide primer is designed to have a base at the $3^{\prime}$ terminal complementary to a mutated base in the DNA sequence. Extension with the primer takes place and chain reaction occurs only when the template DNA bears the expected point mutation (Fig. 1). This method enables non-isotopic detection of point mutations of gene, because the amplified PCR product is easily recognizable by gel electrophoresis with etidium bromide staining.

We were especially interested in follicular carcinoma, in which a diagnosis of malignancy is often difficult, even by histo-pathological examination, and it was initially reported that the frequency of ras gene mutations was high in this type of thyroid cancer [14].

\section{Materials and Methods}

\section{Materials}

DNA samples were obtained from 24 surgically removed thyroid tissues which had been frozen and stored. Control DNA were extracted from the leukocytes of the two healthy volunteers (Table 1). After formalin fixation followed by hematoxylineosin staining, the thyroid tissues were histopathologically diagnosed by experienced pathologists.

\section{DNA preparation}

Tumors in the frozen specimens were carefully ablated from the surrounding normal tissue, homogenized in phosphate buffered saline, and centrifuged with cell lysis buffer $(0.32 \mathrm{M}$ sucrose, $1 \%$ (v/v) triton X-100, $5 \mathrm{mM} \mathrm{MgCl}$, $10 \mathrm{mM}$ Tris- $\mathrm{HCl}$, $\mathrm{pH}$ 7.5) to obtain the nuclear fraction. The nuclear

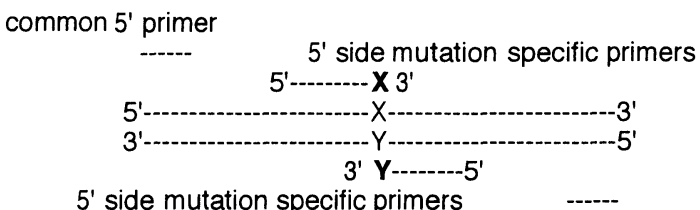

common $3^{\prime}$ primer

Fig. 1. Design of mutation-specific primers. $X$ and $Y$ are mutated bases and are complementary to each other. Mutation specific primers are designed to have a base complementary to a mutated base in the template DNA at their $3^{\prime}$ terminal. Extension reaction occurs only when the template DNA has the expected mutation and PCR products are yielded with these mutation specific primers in combination with corresponding common primers. A combination of $5^{\prime}$ and $3^{\prime}$ common primers yields PCR products in which codon 61 is located in the center of the products. These products are used for dot blot analysis and sequence analysis.

fraction of each specimen was treated with proteinase $\mathrm{K}$, phenol-chloroform extraction and $70 \%$ ethanol sedimentation to purify the DNA.

\section{Mutation specific amplification}

Oligonucleotide primers and probes were synthesized by the solid cyano-ethyl phosphoamide method with a DNA synthesizer (Model 381 Applied Biosystems). Mutation-specific primers were designed to have the base complimentary to the mutated base (Fig. 1). Sequences of the synthesized primers are shown in Table 2. The first 2 primers are common primers for the centromere or telomere side of codon 61 (positions are shown in Fig. 1). Others are specific primers for normal and or mutated alleles.

One $\mu \mathrm{g}$ of genomic DNA samples, $10 \mu l$ of $\times 10$ PCR buffer, $4 \mathrm{mM}$ of dNTP, 2 units of Ampli Taq polymerase, $30 \mathrm{pM}$ of $5^{\prime}$ primer and $30 \mathrm{pM}$ of $3^{\prime}$ primer were adjusted with $\mathrm{H}_{2} \mathrm{O}$ to a volume of 100 $\mu l$. The solutions underwent PCR in a thermal cycler (Perkin-Elmer-Cetus). Amplification was conducted 25 times $\left(94^{\circ} \mathrm{C}, 1 \mathrm{~min} ; 56^{\circ} \mathrm{C}, 2 \mathrm{~min} ; 72^{\circ} \mathrm{C}, 2\right.$ $\mathrm{min})$. The amplified PCR products underwent electrophoresis on $2.5 \%$ agarose gel and staining with ethidium bromide for identification under UV irradiation. 
Table 1. Pathohistological characters of the thyroid tissues

\begin{tabular}{|c|c|c|c|}
\hline Patient no. & Age & Sex & Pathological diagnosis \\
\hline 1 & 43 & male & follicular carcinoma \\
\hline 2 & 33 & female & follicular adenoma \\
\hline 3 & 37 & female & follicular adenoma \\
\hline 4 & 28 & female & follicular carcinoma \\
\hline 5 & 37 & female & adenomatous goiter \\
\hline 6 & 35 & female & adenomatous goiter, Graves' disease \\
\hline 7 & 35 & female & follicular adenoma \\
\hline 8 & 36 & female & follicular carcinoma \\
\hline 9 & 28 & female & adenomatous goiter \\
\hline 10 & 46 & female & Hürthle cell adenoma \\
\hline 11 & 55 & male & papillary carcinoma \\
\hline 12 & 65 & female & follicular carcinoma \\
\hline 13 & 46 & male & follicular carcinoma \\
\hline 14 & 51 & male & follicular adenoma \\
\hline 15 & 53 & female & adenomatous goiter \\
\hline 16 & 47 & male & follicular adenoma \\
\hline 17 & 39 & female & follicular carcinoma \\
\hline 18 & 44 & female & follicular adenoma \\
\hline 19 & 39 & female & adenomatous goiter \\
\hline 20 & 42 & male & adenomatous goiter \\
\hline 21 & 60 & female & follicular carcinoma \\
\hline 22 & 40 & male & Graves' disease \\
\hline 23 & 56 & female & adenomatous goiter \\
\hline 24 & 65 & female & adenomatous goiter \\
\hline 25 & 24 & female & control \\
\hline 26 & 32 & male & control \\
\hline
\end{tabular}

Table 2. Synthesized primers for PCR amplification

\begin{tabular}{llc}
\hline \multicolumn{1}{c}{ Primer } & \multicolumn{1}{c}{ Sequence } & Position \\
\hline N-ras common 5' & 5'-GGTGAAACCTGTTTGTTG-3' & $142-159$ \\
N-ras common 3' & 5'-ATTATTGATGGCAAATAC-3' & $241-258$ \\
N-ras 61 1N 5' & 5'-CATACTGGATACAGCTGGAC-3' & $162-181$ \\
N-ras 61 2N 5' & 5'-ATACTGGATACAGCTGGACA-3' & $163-182$ \\
N-ras 61 1A 5' & 5'-CATACTGGATACAGCTGGAa-3' & $162-181$ \\
N-ras 61 2G 5' & 5'-ATACTGGATACAGCTGGACg-3' & $164-182$ \\
N-ras 61 1T 3' & 5'-ATGGCACTGTACTCTTCTTt-3' & $181-200$ \\
N-ras 61 2C 3' & 5'-CATGGCACTGTACTCTTCTc-3' & $182-201$ \\
\hline
\end{tabular}

Small letters at the $3^{\prime}$ terminal indicate bases corresponding to mutated bases.

\section{Dot blot hybridization and direct sequencing}

To confirm the detected mutations, dot blot hybridization and direct sequence of amplified DNA were performed. DNA fragments which contained $\mathrm{N}$-ras codon 61 were amplified by PCR. The PCR were planned to locate $\mathrm{N}$-ras codon 61 in the mid portion of the products using the first two primers

\section{in Table 2.}

Dot blot hybridization was performed [21] with three radio-labelled probes: (A) N-ras 61 normal probe, normal sequence of N-ras codon 61 (5'ACAGCTGGACAAGAAGAGTA-3'), (B) N-ras 611A probe, mutated sequence of $\mathrm{N}$-ras codon 61 at the first base, substituting the adenine for cytosine (5'-ACAGCTGGAâAAGAAGAGTA-3') and (C) Nras $61-2 \mathrm{G}$ probe, mutated sequence of $\mathrm{N}$-ras codon 
61 at the second base, substituting guanine for adenine (5'-ACAGCTGGACgAGAAGAGTA-3').

For sequencing, amplified double strand DNA were further purified by agarose gel electrophoresis followed by extraction. Sequencing was performed by the dideoxy method using double strand DNA and appropriate ${ }^{32} \mathrm{P}$ labeled primers [25]. Probes for dot blot hybridization and primers for direct sequencing were labeled with ${ }^{32} \mathrm{P}$ by polynucleotide kinase.

\section{Results}

\section{PCR condition}

The annealing temperature, template volume, and number of reaction cycles were varied to evaluate the efficiency of the PCR protocol employed. Templates used for this evaluation were those of case 12 (mutated) and case 25 (control). The results were as follows:

1. The annealing temperature was evaluated in 2 degree intervals from $55^{\circ} \mathrm{C}$ to $65^{\circ} \mathrm{C}$. Amplification was satisfactory within the range $55-63^{\circ} \mathrm{C}$. A small amount of non-specific product was observed at lower temperatures. (Fig. 2-A)

2. The template amount was varied from $100 \mathrm{ng}$ to $150 \mathrm{ng}, 250 \mathrm{ng}, 500 \mathrm{ng}, 750 \mathrm{ng}$ and $1 \mu \mathrm{g}$. No amplified product was observed with $100 \mathrm{ng}$ of template DNA. (Fig. 2-B)

3. PCR amplification was conducted 25 times, 30 times and 35 times. Amplification was satisfactory at any of the three alternatives.

\section{Mutation-specific PCR amplification}

Figure 3 shows the products of mutation specific PCR. With the combination of primers N-ras $611 \mathrm{~A}$ $5^{\prime}$ and N-ras 61 common 3' (A), and primers N-ras 61 common $5^{\prime}$ and N-ras 61 1T 3' (B), significant amplification was observed with DNA from case 17 (follicular carcinoma) as the template. Both sets of results are the same, which indicates the existence of DNA bearing adenine at the first base of codon 61 in case 17. With a combination of primers N-ras $612 \mathrm{G} 5^{\prime}$ and N-ras common 3' (C), amplification was observed in DNA from case 1 to 8,9 , $12,13,15,16,17,20,21,23$, and 24 . With a combination of primers N-ras common $5^{\prime}$ and N-ras 61 2C3' (D), significant amplification was observed in the DNA sample of case 12, which indicates that the DNA of case 12 has guanine at the first base of codon 61. These results suggest that only DNA from case 12 has guanine at the second base of codon 61, and that the amplified bands of other samples shown in Fig. 3C were false positive. A weaker band was also observed in case 24 (Fig. 3D). The DNA segments encompassing N-ras codon 61 from cases 17 and 12 were also amplified by primers having bases at 3 ' terminal complementary to the normal first and second base of codon 61 , respectively. Since they were also amplified with mutation-specific primers, case 17 was heterozygous at the first base, and case 12 was heterozygous at the second base of codon 61 .

\section{Dot blot hybridization}

Mutation was also analyzed by dot blot hybridization. With probe A (normal), all samples dem-

(A)

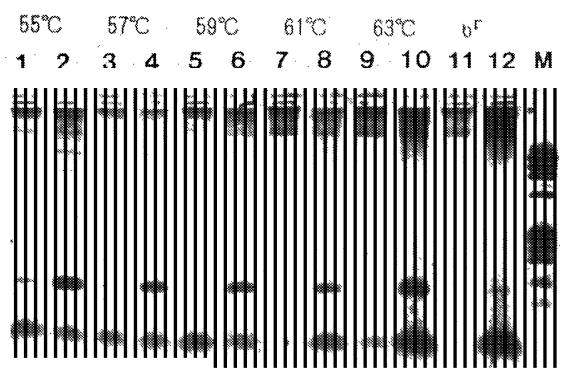

(B)

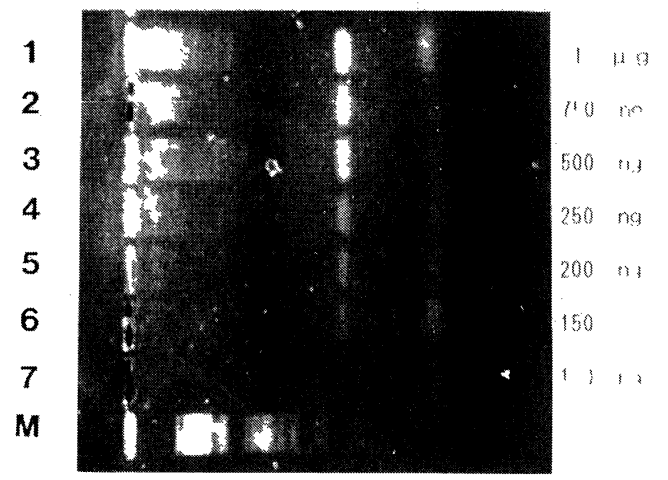

Fig. 2. Evaluation of efficiency of PCR. (A) Annealing temperature; Lane $1,2: 55^{\circ} \mathrm{C}$, Lane $3,4: 57^{\circ} \mathrm{C}$, Lane 5, 6: $59^{\circ} \mathrm{C}$, Lane 7, 8: $61^{\circ} \mathrm{C}$, Lane 9, $10: 63^{\circ} \mathrm{C}$, Lane 11, 12: $65^{\circ} \mathrm{C}$. Lanes with odd numbers are samples of case 12 (mutated) and lanes with even numbers are samples of case 25 (control). (B) Template amount; Lane 1: $1 \mu \mathrm{g}$, Lane 2: $750 \mathrm{ng}$, Lane 3: $500 \mathrm{ng}$, Lane 4: $250 \mathrm{ng}$, Lane 5:150 ng, Lane 6: $100 \mathrm{ng}$. 
onstrated hybridization. Probe B (61-1A) hybridized only to the amplified product of case 17 and probe $C(61-2 G)$ only to the amplified product of case 12, which further indicated that cases 12 and 17 were heterozygous (Fig. 4).

(A)

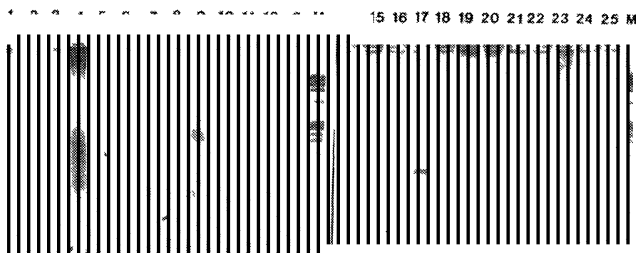

(B)

(C)
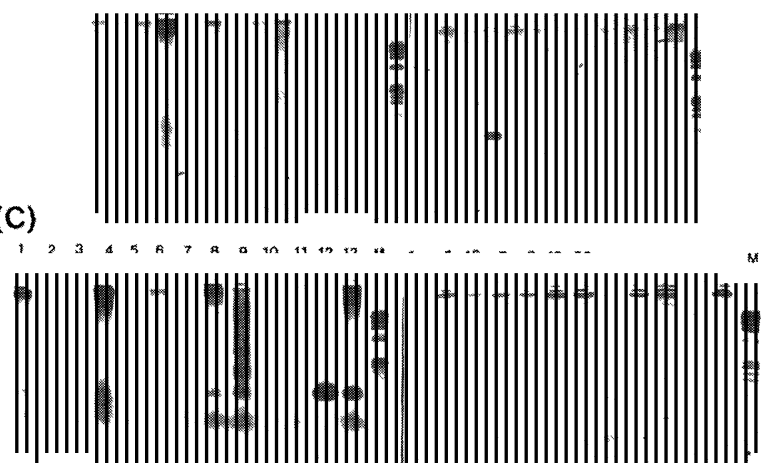

(L)

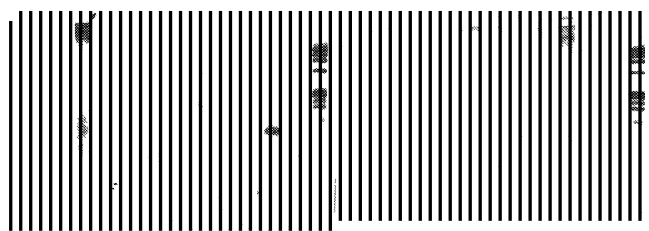

Fig. 3. Results of mutation-specific PCR amplification. (A) Results of primer combination of N-ras 61 1A $5^{\prime}$ and $\mathrm{N}$-ras common $3^{\prime}$ for detecting point mutation at the first base of $\mathrm{N}$-ras codon 61 in the antisense strand. Significant amplification is observed in case No. 17. (B) Results of primer combination of N-ras common $5^{\prime}$ and N-ras 61 1T $3^{\prime}$ for detecting point mutation at the first base of $\mathrm{N}$-ras condon 61 in the sense strand. Significant amplification is observed in case No. 17. (C) Results of primer combination of $\mathrm{N}$-ras $612 \mathrm{G} 5^{\prime}$ and N-ras common $3^{\prime}$ for detecting point mutation at the second base of $\mathrm{N}$-ras condon 61 in the antisense strand. Amplification of case Nos. 1, 8, 9, 12, 13, 15, 16, 17, 20, 21, 23 and 24 are observed. (D) Results of primer combination of $\mathrm{N}$ ras 61 common $5^{\prime}$ and $\mathrm{N}$-ras $612 \mathrm{C}^{\prime}$ ' for detecting point mutation at the second base of $\mathrm{N}$-ras condon 61 in the sense strand. Abundant amplified band was observed in case No. 12. There is also scant band in case No. 24. M, MW markers $\varnothing 174$ digested by Hae III.
(A)

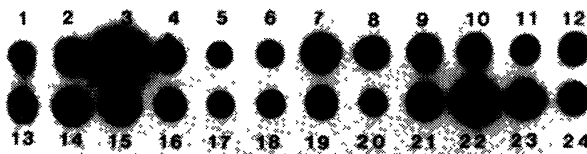

(B)
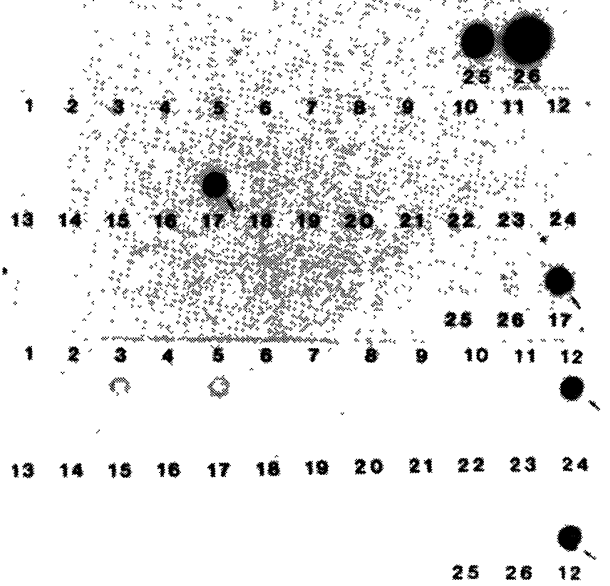

Fig. 4. Results of oligonucleotide specific hybridization of codon 61 of N-ras gene. (A) probe: N-ras 61 normal 5'-ACAGCTGGACAAGAAGAGTA-3'. All templates hybridized. (B) probe: N-ras $611 \mathrm{~A} 5^{\prime}$ ACAGCTGGAạAAGAAGAGTA-3'. Only case No. 17 hybridized. (C) probe: N-ras 61 2G 5'ACAGCTGGACgAGAAGAGTA-3'. Only case No. 12 hybridized.

\section{Direct sequencing}

DNA segments encompassing the $\mathrm{N}$-ras codon 61 of two healthy subjects and cases 12 and 17 were amplified by PCR with $5^{\prime}$ and $3^{\prime}$ common primers and directly sequenced by the dideoxy method. In case 17, at the site of the 1st base of codon 61 , two bands of adenine and cytosine were detected (Fig. 5). Similarly, at the site of the second base of $\mathrm{N}$-ras codon 61 in case 12, guanine can be seen in addition to normal base adenine (Fig. 6). These are the same outcomes as obtained by the mutation-specific PCR technique and dot blot analysis. None of the DNA samples from the healthy control subjects showed signs of abnormalities.

\section{Discussion}

By means of the mutation specific amplification technique, point mutations at $\mathrm{N}$-ras codon 61 were 


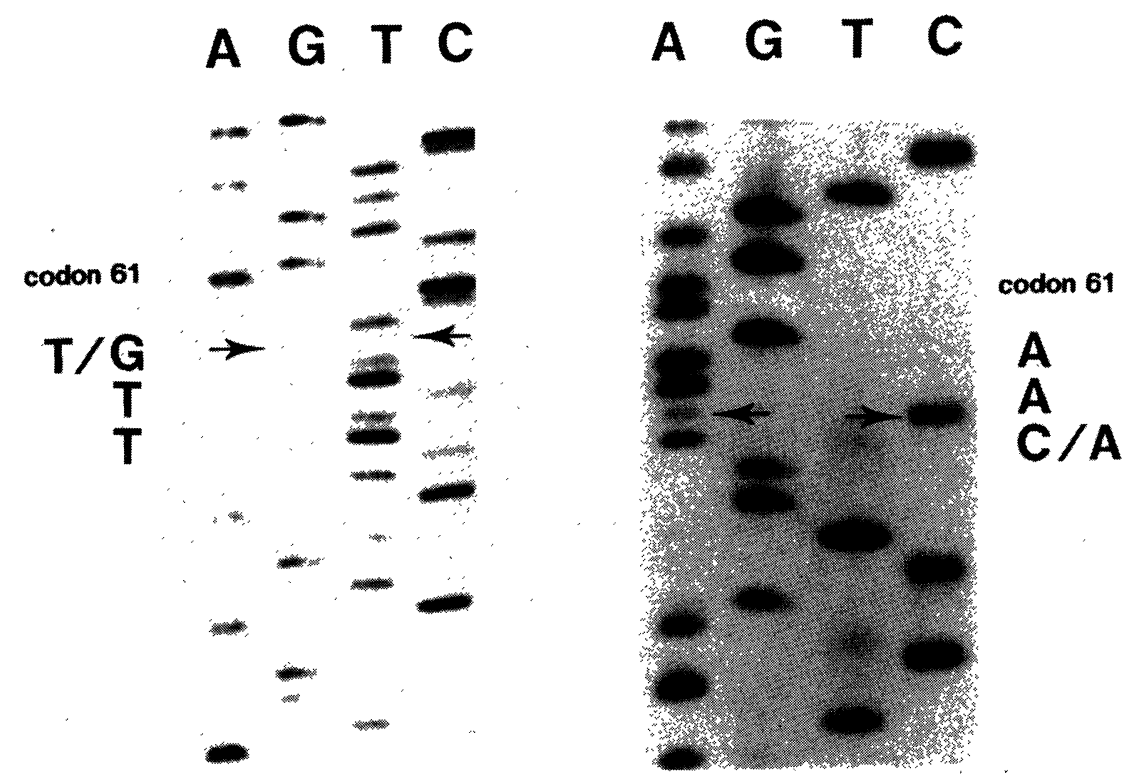

Fig. 5. Results of direct sequencing of N-ras gene of case No. 17. The left side is a result of the sequence of antisense and the right is that of the sense chain. Each result shows double bands of the base at the first base of codon 61 . They mean heterozygous.

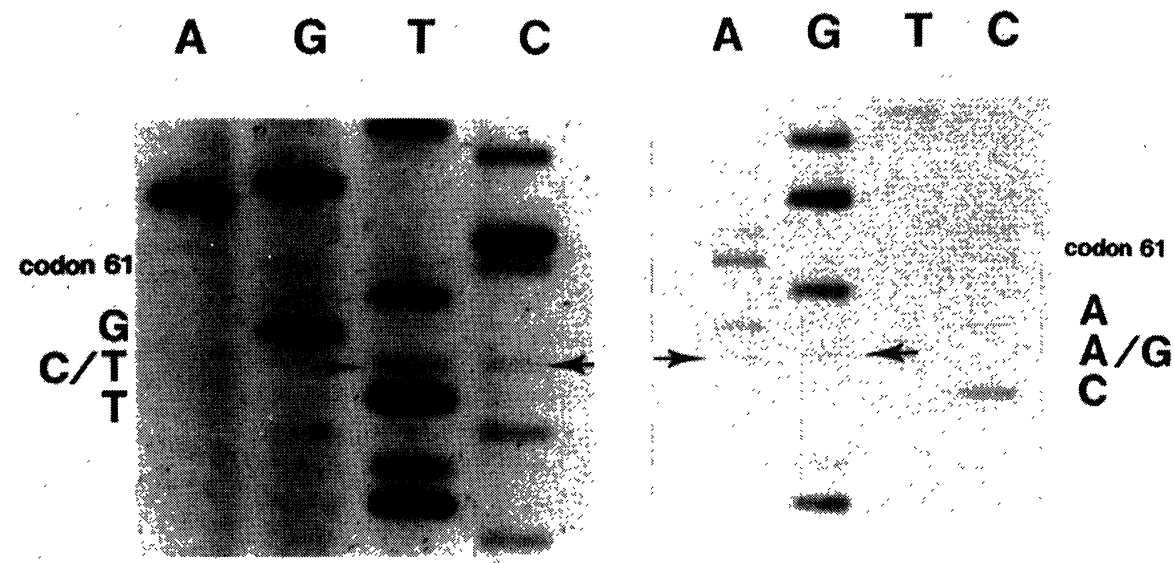

Fig. 6. Results of direct sequencing of N-ras gene of case No. 12. The left side is a result of the sequence of antisense and the right is that of the sense chain. Each result shows double bands of the base at the second base of codon 61 . They mean heterozygous.

detected in 2 follicular carcinomas out of 23 thyroid neoplastic tissues. One of the mutations was the substitution of adenine for cytosine at the site of the first base, and the other was the substitution of guanine for adenine at the site of the second base. The results agreed with those of dot blot hybridization using probes corresponding to the mutations. Confirmation of the outcome was also made by direct sequencing. These type of mutations were not detected in other thyroid tissues including 7 follicular adenomas and 1 papillary carcinoma.

Dot blot hybridization, PCR-restriction fragment length polymorphism analysis (PCR-RFLP) [26], and direct sequencing have been used in identifying point mutations in genes. PCR-single strand 
conformation polymorphism (PCR-SSCP) [27] analysis has been also employed as a screening method which detects the presence of mutations but provides no information about the nature of the mutations.

Dot blot hybridization and PCR-RFLP are methods used to detect mutation whose nature is already known. To detect an unknown mutation, direct sequencing is conducted. Since the nature of mutations at the N-ras genes is known, they are usually detected by dot blot hybridization [22]. This method has the advantage of being able to treat a large number of samples. On the other hand, disadvantages are the occasional false positives or false negatives and the necessity of radioisotopic work which diminishes its convenience. The sequencing procedure can detect mutations whose nature is not known, but it is technically demanding, treat only a limited number of samples, and need to be performed in research laboratories. These methods also lack sufficient sensitivity when only a small portion of a tissue sample bears mutations. PCR-RFLP analysis can only be used when a restriction enzyme with a cleavage site corresponding to the base sequence of the mutation site is available.

Mutation-specific amplification enables the detection of point mutations with one round of PCR, requires no use of isotopes, and hence greatly simplifies the protocol. The mutation-specific technique is theoretically able to detect small amounts of mutated DNA in a tissue sample. Its disadvantage is, like dot blot hybridization, the occurrence of false positives. In the present study, amplifica- tion with primer $61-1 \mathrm{~A} 5^{\prime}$ is highly specific. Amplification with primer $61-2 \mathrm{G} 5^{\prime}$, however, produced a number of PCR products when annealing was conducted at a lower temperature. Primer 61 2G $5^{\prime}$ may produce an amplification with a rather low specificity when used in the primer combination employed in this study.

In PCR procedures, the selection of primers is very important. Although the combinations of primers are limited in mutation specific amplification by the fact that the $3^{\prime}$ terminal of one primer is fixed, selection of the other primer may increase the specificity of the outcome.

The false positives which occurred at a lower annealing temperature may indicate the presence of minimal amounts of mutations. This seems not to be the case because amplification occurred even in the normal control. Although our protocol could not completely rule out this possibility, it is a very useful screening method as it is simple and examines a large number of samples at one time.

In this study, we have studied only $\mathrm{N}$-ras codon 61 and found point mutations in 2 out of 7 follicular carcinomas $(29 \%)$. Although the incidence of mutation at $\mathrm{N}$-ras codon 61 in thyroid cancers is lower than in cancer of hematopoietic tissues and the pancreas, the activation of N-ras protein caused by gene mutations seems to play a significant role in follicular carcinoma of the thyroid gland.

To understand the formation of thyroid cancer, mutations of other cancer related genes remain to be elucidated. In such investigations, mutationspecific PCR amplification is a very effective screening method.

\section{References}

1. Saiki RK, Gelfand DH, Stoffe S, Scharf SJ, Higuchi R, Horn GT, Mullis KB, Erlich HA (1988) Primerdirected enzymatic amplification of DNA with a thermostable DNA polymerase. Science 239: 481491.

2. Land H, Parade LF, Weinberg RA (1983) Tumorigenic conversion of primary embryo fibroblasts requires at least two cooperating oncogenes. Nature 304: 596-602.

3. Vogelstein B, Fearon ER, Hamilton SR, Kern SE, Preisinger AC, Leppert M, Nakamura $Y$, White R, Smits AMM, Bos JL (1988) Genetic alterations during colorectal-tumor development. $N$ Engl J Med 319: 525-532.
4. Bos JL, Fearon ER, Hamilton SR, de Vries MV, van Boom JH, van der Eb AJ, Vogelstein B (1987) Prevalence of ras gene mutations in human colorectal cancers. Nature 327: 293-297.

5. Nigro JM, Baker SJ, Preisinger AC, Jessup JM, Hostetter R, Cleary K, Bigner SH, Davidson N, Baylin S, Devilee P, Glover T, Collins FS, Weston A, Modali R, Harris CC, Vogelstein B (1989) Mutations in the $\mathrm{p} 53$ gene occur in diverse human tumor types. Nature 342: 705-708.

6. Kinzler KW, Nilbert MC, Su LK, Vogelstein B, Bryan TM, Levy DB, Smith KJ, Preisinger AC, Hedge P, McKechnie D, Finniear R, Markham A, Groffen J, Boguski MS, Altshul SF, Horii A, Ando 
H, Miyoshi Y, Miki Y, Nishisho I, Nakamura Y (1991) Identification of FAP locus genes from chromosome 5q21. Science 253: 661-665.

7. Fearon ER, Cho KR, Nigro JM, Kern SE, Simons JW, Ruppert JM, Hamilton SR, Preisinger AC, Thomas G, Kinzler KW, Vogelstein B (1990) Identification of a chromosome $18 \mathrm{q}$ gene that is altered in colorectal cancers. Science 247: 49-56.

8. Sasaki M, Okamoto M, Sato C, Sugio K, Soejima J, Iwama T, Ikeuchi T, Tonomura A, Miyaki M, Sasazuki T (1989) Loss of constitutional heterozygosity in colorectal tumors from patients with familial polyposis coli and those with nonpolyposis colorectal carcinoma. Cancer Res 49: 4402-4406.

9. Fagin JA (1992) Molecular defects in thyroid gland neoplasia. J Clin Endocrinol Metab 75: 1398-1400.

10. Wynfold-Thomas D (1993) Molecular genetics of thyroid cancer. Trends Endocrinol Metab 4: 224-232.

11. Lemoine NR, Mayall ES, Wyllie FS, Williams ED, Goyns M, Stringer B, Wynford-Thomas D (1989) High frequency of ras oncogene activation in all stages of human thyroid tumorigenesis. Oncogene 4: 159-164.

12. Fagin JA, Matuo $K$, Karmakar A, Chen DL, Tang $\mathrm{SH}$, Koeffler HP (1993) High prevalence of mutations of the p53 gene in poorly differentiated human thyroid carcinomas. I Clin Invest 91: 179184.

13. Grieco M, Santoro M, Berlingieri MT, Melillo RM, Donghi R, Bongarzone I, Pierotti MA, Porta GD, Fusco A, Vecchio G (1990) PTC is a novel rearranged form of ret proto-oncogene and is frequently detected in vivo in human thyroid papillary carcinomas. Cell 60: 557-563.

14. Lemoine NR, Mayall ES, Wyllie FS, Farr CJ, Hughes D, Padua RA, Thurston V, Williams ED, Wynford-Thomas D (1988) Activated ras oncogenes in human thyroid cancer. Cancer Res 48: 4459-4463.

15. Namba H, Gutman RA, Matuo K, Alvarez A, Fagin JA (1990) H-Ras protooncogene mutations in human thyroid neoplasms. J Clin Endocrinol Metab 71: 223-229.

16. Suarez HG, du Villard JA, Severino M, Caillou B, Schlumberger M, Tubiana M, Parmentier C,
Monier R (1990) Presence of mutations in all three ras genes in human thyroid tumors. Oncogene 5: 565-570.

17. Karga H, Lee JK, Vickery AL, Thor A, Gaz RD, Jameson JL (1991) Ras oncogene mutations in benign and malignant thyroid neoplasms. J Clin Endocrinol Metab 73: 832-836.

18. Barbacid M (1987) ras GENES. Ann Rev Biochem 59: 779-827.

19. Taparowsky E, Shimizu K, Goldfarb M, Wigler M (1983) Structure and activation of the human N-ras gene. Cell 34: 581-586.

20. Johnson TJ, Lloyd RV, Thor A (1987) Expression of ras oncogene p21 antigen in normal and proliferative thyroid tissues. Am J Pathol 127: 60-65.

21. Saiki RK, Bugawan TL, Horn GT, Mullis KB, Erlich HA (1986) Analysis of enzymatically amplified $\beta$ globin and HLA-DQ $\alpha$ DNA with allele-specific oligonucleotide probes. Nature 324: 163-166.

22. Vries MV, Bogaard ME, van den Elst $H$, van Boom $\mathrm{JH}$, van der Eb AJ, Bos JL (1986) A dot-blot screening procedure for mutated ras oncogene using synthetic oligodeoxynucleotides. Gene 50: 313-320.

23. Okayama H, Curiel DT, Brantly ML, Holmes MD, Crystal RG (1989) Rapid, non radioactive detection of mutations in the human genome by allele-specific amplification. J Lab Clin Med 114: 105-113.

24. Wu DY, Ugozzoli L, Pal BK, Wallace RB (1989) Allele-specific enzymatic amplification of $\beta$-globin genomic DNA for diagnosis of sikle cell anemia. wProc Natl Acad Sci USA 86: 2757-2760.

25. Sanger F, Nicklen S, Coulson AR (1977) DNA sequencing with chain terminating inhibitors. Proc Natl Acad Sci USA 74: 5643-5647.

26. Saiki RK, Scharf S, Faloona F, Mullis KB, Horn GT, Erlich HA, Arnheim N (1985) Enzymatic amplification of $\beta$-globin genomic sequences and restriction site analysis for diagnosis of sickle cell anemia. Science 230: 1350-1354.

27. Orita M, Iwahana $H$, Kanazawa $H$, Hayashi K, Sekiya T (1989) Detection of polymorphisms of human DNA by gel electrophoresis as singlestrand conformation polymorphisms. Proc Natl Acad Sci USA 86: 2766-2770. 